\title{
Российско-французский семинар 2015
}

\section{Russian-French seminar 2015}

6-9 мая 2015 г. в Санкт-Петербурге проходил очередной российско-французский семинар «Ледниковые архивы данных о климате и окружающей среде», который продолжил начатую в 2002 г. традицию ежегодных российско-французских семинаров, посвящённых исследованиям ледяных антарктических кернов, палеоклимата и подледниковых озёр Антарктиды. Семинар, в котором участвовали 67 специалистов из 12 научно-исследовательских учреждений России, Франции и Эстонии, проводился на двух площадках - в Национальном минеральносырьевом университете «Горный» и в ААНИИ.

Научная программа семинара содержала все основные направления совместных исследований российских и французских учёных, которые в настоящее время проводятся в рамках деятельности Международной ассоциированной лаборатории, созданной в 2012 г. и ставшей преемницей российско-французского Европейского научно-исследовательского объединения «Восток» (2004-2012). В докладах сотрудников упомянутой лаборатории были представлены новые результаты исследований в следующих областях совместной деятельности: разработка методов и средств бурения полярных ледников; поиск и исследование древнейшего на планете антарктического льда возрастом 1,5 млн лет; развитие новых геохимических и физических методов анализа ледяных кернов; палеоклиматические реконструкции по данным глубоких кернов Антарктиды и ледяного керна, полученного на Западном плато горы Эльбрус специалистами Института географии РАН; исследования подледникового озера Восток. По материалам докладов, посвящённых результатам исследований ледяных кернов Антарктиды и Эльбруса, написаны три статьи, две из которых опубликованы в этом номере журнала.

Отличительной особенностью российскофранцузского семинара 2015 г. стало участие в нём четырёх поколений российских и французских гляциологов - исследователей ледяных кернов. Дело в том, что в рамках семинара праздновался 90-летний юбилей одного из старейших сотрудников ААНИИ, пионера глубокого бурения на станции Восток - Нарцисса Иринарховича Баркова. На встречу с ним в Санкт-Петербург приехали его друзья и коллеги, стоявшие у истоков российскофранцузского сотрудничества на Востоке - самый известный из ныне здравствующих французских полярных исследователей Клод Лориус и академик РАН, Почетный Президент Русского географического общества Владимир Михайлович Котляков.

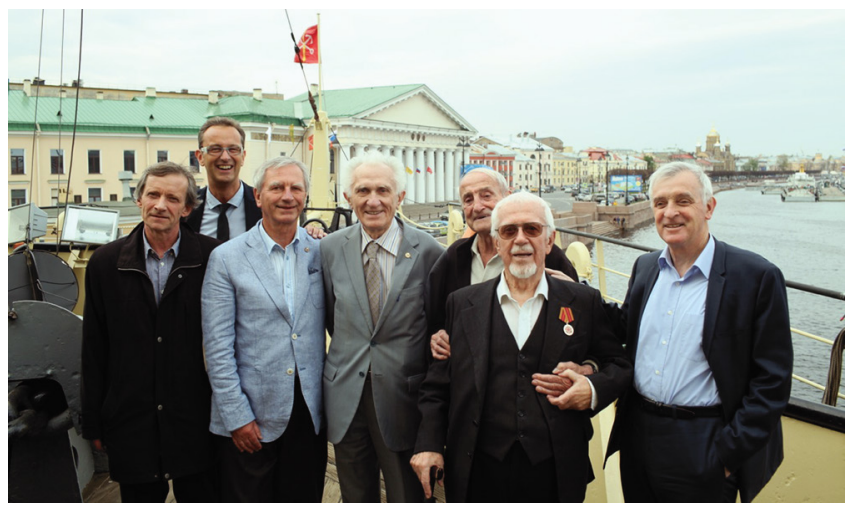

На борту ледокола Красин 7 мая 2015 г.

Слева направо: Владимир Липенков, Жером Шаппеллаз, Доминик Райно, Владимир Котляков,

Клод Лориус, Нарцисс Барков и Жан Жузель. Обе фотографии предоставлены ассоциацией «Wild-Touch»

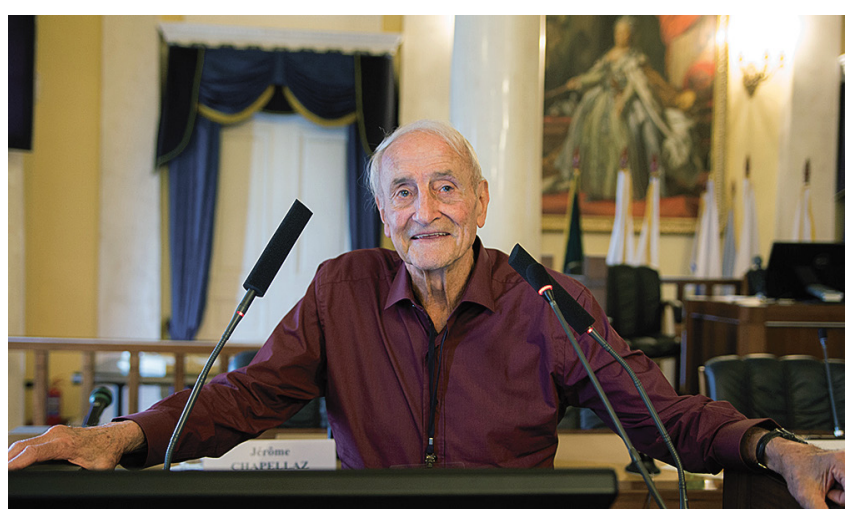

Выступление Клода Лориуса в Национальном минерально-сырьевом университете «Горный» после презентации фильма Люка Жаке «Лёд и небо»

Работа семинара и юбилей Н.И. Баркова освещались представителями прессы и группой кинодокументалистов из команды Люка Жаке - директора ассоциации «Wild-Touch», обладателя Оскара за документальный фильм «Марш императоров». Во время семинара состоялась презентация нового фильма Люка Жаке «Лёд и небо» (Ice and the Sky), в котором рассказывается, как исследования ледяных кернов Антарктиды и Гренландии помогли осознать ту реальную опасность, которую несут человечеству происходящие на Земле глобальные изменения природной среды. Проект глубокого бурения на станции Восток и тема российско-французского сотрудничества нашли в фильме достойное отражение.

Ж. Шаппеллаз, В.Я. Липенков 